\section{Vol. 66, No. 17}

In the report "Addressing a Yellow Fever Vaccine Shortage United States, 2016-2017," on page 457, the first sentence of the fourth paragraph should have read "In 2015, approximately 9.5 million aviation passenger-journeys from the United States to $\mathbf{4 2}$ countries with endemic yellow fever virus transmission occurred (1) (Data In, Intelligence Out [https://www.diio.net], unpublished data, 2016).”

\section{Vol. 66, No. 17}

In the report "Vital Signs: Racial Disparities in Age-Specific Mortality Among Blacks or African Americans - United States, 1999-2015," on page 446, under "Results," the last sentence of the first paragraph should have read "Among adults aged $\geq 65$ years, the death rate in 2015 relative to that in 1999 declined $27 \%$ for blacks and $17 \%$ for whites, resulting in a crossover in death rates after 2010, when blacks had lower age-specific death rates than whites."

On page 447, the first sentence of the first paragraph should have read, "Among persons aged $\geq 65$ years, there was a blackwhite mortality crossover, whereby blacks had slightly lower age-specific death rates than whites after 2010." 